グローバル時代の脳神経外科

一若手へのメッセージー

伊達 勲, 村井 智

岡山大学大学院医歯薬学総合研究科脳神経外科

\title{
Neurosurgery in the Global Era: A Message to Young Neurosurgeons
}

\section{Isao Date, M.D., and Satoshi Murai, M.D.}

Department of Neurological Surgery, Okayama University Graduate School of Medicine, Dentistry and Pharmaceutical Sciences

The unexpected coronavirus pandemic has markedly reduced travel to and from Japan; however, we expect that the problem will be resolved in time and the global era will return to normal. The number of neurosurgeons studying abroad was on an upward trend compared to previous years. This article presents the results of a questionnaire survey on Japanese neurosurgeons studying abroad. In addition, it included advantages and disadvantages of studying abroad, the direction at which academia is heading in the global era, the importance of English as a communication language, and global activities of the Japan Neurosurgical Society and Japanese Congress of Neurological Surgeons. Finally, the concept of global neurosurgery is introduced.

(Received November 4, 2020 ; accepted November 12, 2020)

Key words : neurosurgeons, study abroad, global era

Jpn J Neurosurg (Tokyo) $30: 208^{-215,2021}$

\section{はじめに}

2020 年の第 40 回日本脳神経外科コングレス総会にお いて,「グローバル時代の脳神経外科: 若手へのメッセー ジ」のタイトルで講演するようにと会長の中田光俊先生 からご下命を受けた。 2019年時点では日本へのインバウ ンド，日本からのアウトバウンドとも史上最高の数字を 上げていた頃であり，本稿に揭載する全国の脳神経外科 医の留学に関するアンケート結果なども当時のデー夕に 基づいている.

その後, 思いもよら新型コロナウイルス感染症の蔓 延が全世界に及び，インバウンド，アウトバウンドとも
ほとんど停止した状態となっている(2020年10月現在). しかしながら，人類はこの感染症をワクチンや新薬の開 発により必ずや克服し，再びグローバル時代がやってく るであろうと確信している。本稿は，そのようなグロー バル時代に生きる若手脳神経外科医を励ます内容とした い.

\section{日本の脳神経外科医の外国留学の現状 一アンケート結果一}

2013 年に文部科学省が「トビタテ! 留学 JAPAN」のプ ランを発表し ${ }^{4)}$, 日本人学生の留学者数を 2 倍にするこ

連絡先: 伊達 勲, $\overline{\mathbf{T}} 700-8558$ 岡山市北区鹿田町 2-5-1 岡山大学大学院医歯薬学総合研究科脳神経外科

Address reprint request to: Isao Date, M.D., Department of Neurological Surgery, Okayama University Graduate School of Medicine, Dentistry and Pharmaceutical Sciences, 2-5-1 Shikata-cho, Kita-ku, Okayama-shi, Okayama 700-8558, Japan 


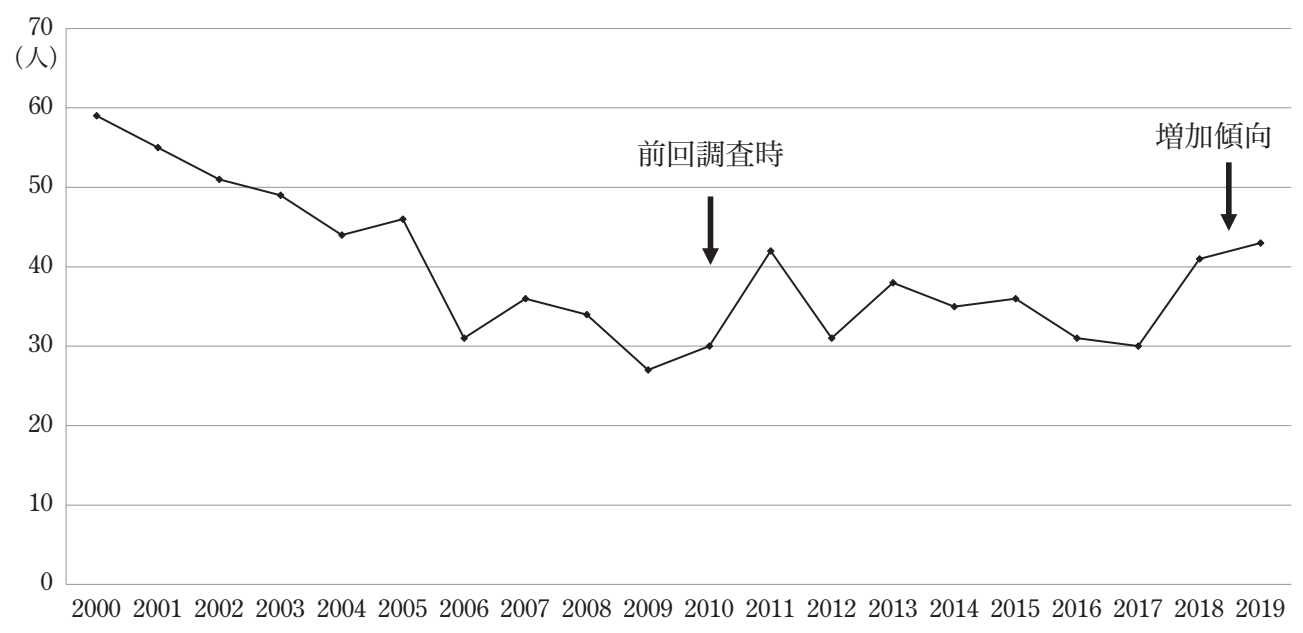

Fig. 1 The number of neurosurgeons studying abroad nationwide There has been a mild upward trend since the last survey in 2010 .

とを目標とした。日本学生支援機構が発表している日本 人学生の留学者数によると, 現時点において，2013 年の 数字に比べて 2 倍にはまだ到達していないが，右肩上が りの状況が続いている。 また，文部科学省が発表してい る日本への外国人留学生数の推移は, 強い右肩上がりで ある5)。では，日本の脳神経外科医の外国留学はごのよ うな状況にあるか，を今回調査することにした。

参考にしたのは, 2012 年滋賀医科大学の野崎和彦先生 が本誌に発表した「海外留学の実態調査および海外での 基礎研究の意義」6)である。このときのデータ収集期間が 2000 2010 年であるので, 野崎先生の許可をいただいて 同様のアンケートを行い, 2011〜2019 年までのデー夕を 収集した。これによって 2010 年までの 10 年間と, 2010 年以降の 9 年間の比較を行うことができた。

2019 年 12 月上旬に, 全国 80 大学の脳神経外科主任教 授宛に, 過去 9 年間 $(2011$ 年 2019 年) の海外留学者り ストの作成を依頼した。記入項目は，出発年，出発時年 齢，性別，卒後年数，出発時の役職・地位，留学期間, 留学先 (国), 留学目的, 帰国時の役職・地位, 本人の満 足度（満足, やや満足, 普通, やや不満, 不満) であり, これらの項目は野崎先生の論文 ${ }^{6)}$ と同じである。回答は 全国 80 大学すべてからいただいた。

全国の留学者数の推移を Fig. 1 に示す。 2010 年時点で は 30 名で, 2000 年の 59 名から半減していたが, その後 少しずつ増加傾向にある。 2019 年は 43 名である。留学 目的別の留学者数の変遷について, Fig. 2 に示す. 2000 年当時は大半が研究留学であったが, 2010 年以降は臨床 留学が増える傾向にある。これは次の国別留学者数の変 化（Fig. 3）にも関係がある。つまり，米国での臨床留学
は資格などの面で容易ではないが，ドイッやフランスな ぞヨーロッパでは上司の指導下にあれば，臨床を実際に 経験できることが多い．Fig. 3 は，留学先として，2000〜 2010 年に比べて 2011〜2019 年では米国の割合が減り, ドイツ・フランスの割合が増えていることを示してい る．また，出発時年齢別の留学者数であるが (Fig. 4), 30 歳代後半が一番多くなっている. 前回の調査では 30 歳代前半が一番多かったが，卒後臨床研修制度により， 専攻医として脳神経外科研修を開始するのが以前より 2 年遅れていることが影響しているものと思われる．外国 留学について，年代別にその満足度を尋ねたのが Fig. 5 である。いずれの年代で留学した者も満足あるいはやや 満足が大部分であり，外国留学で得るものが多いことを 示している。留学前後の役職についてのグラフが Fig. 6 である。ほとんどの場合，留学前と同じ役職に戻ってい ることがわかる。脳神経外科医の外国留学の現状をまと めたものが Table 1 であり, 留学の現状を示している.

\section{外国留学の利点と課題}

外国留学の利点は,

(1)実際に現地で生活して異文化を学ぶことができる.

(2)外国語（多くは英語）の習得ができる.

(3)研究留学の場合：豊富なグラントを得ているラボに 所属すれば，研究のみに専念できる環境が与えられるこ とが多い。

(4)臨床留学の場合： 1 施設の症例数が日本に比べて多 いため，短期間で多くの症例を学ぶことができる。 などが挙げられる。 


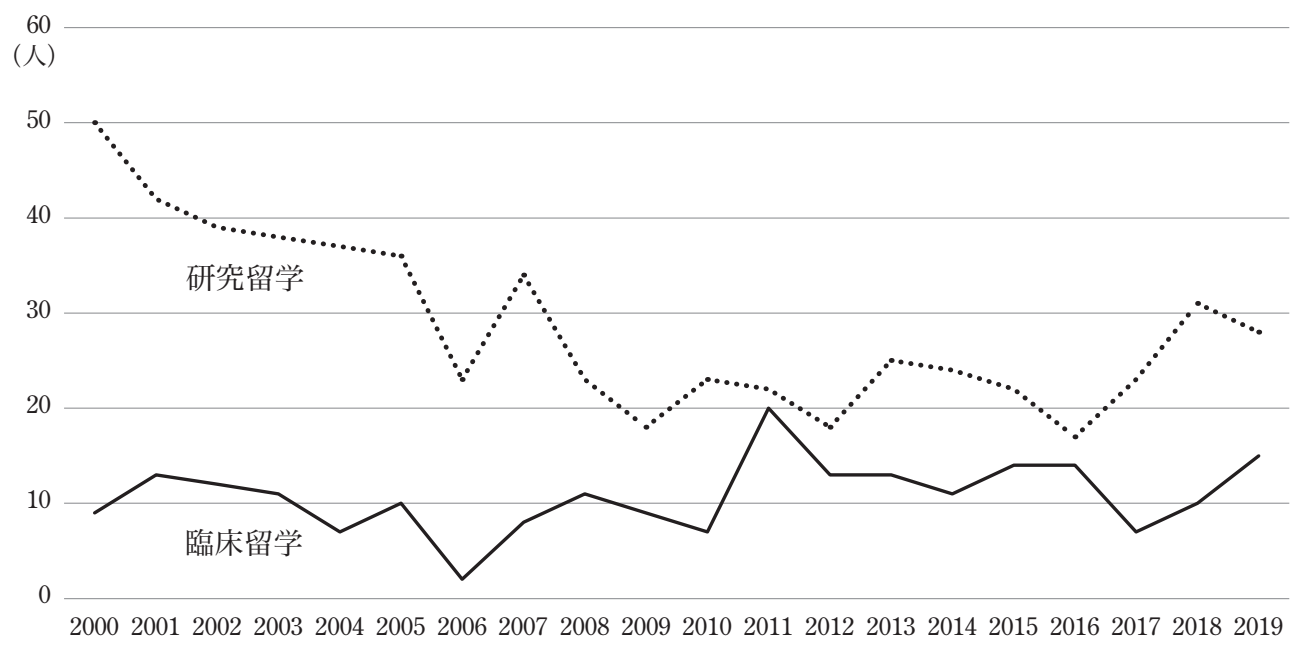

Fig. 2 Changes in the number of neurosurgeons studying abroad based on the main purpose

In 2000 , the majority of neurosurgeons were studying abroad for research, but since 2011, there has been an increase in clinical studies.

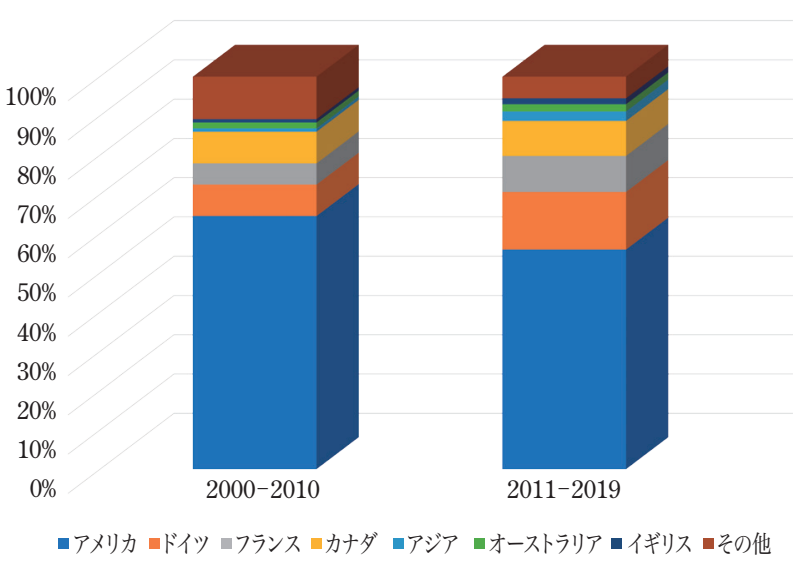

Fig. 3 Number of Japanese students abroad by destination

Since 2011, the percentage of Japanese students in America has decreased, while students in Germany and France increased.

一方，課題は，

(1)留学先に十分なグラントがあればよいが，そうでな い場合に，海外留学助成の資金源が多くない（増えつつ はあるが)。

(2)家族，特に子どもの教育の問題 などが挙げられる。

\section{グローバル時代を表すアカデミアなどの動向}

アカデミアなどでグローバル時代への対応がさまざま な面でなされていることを脳神経外科医も知っておくこ

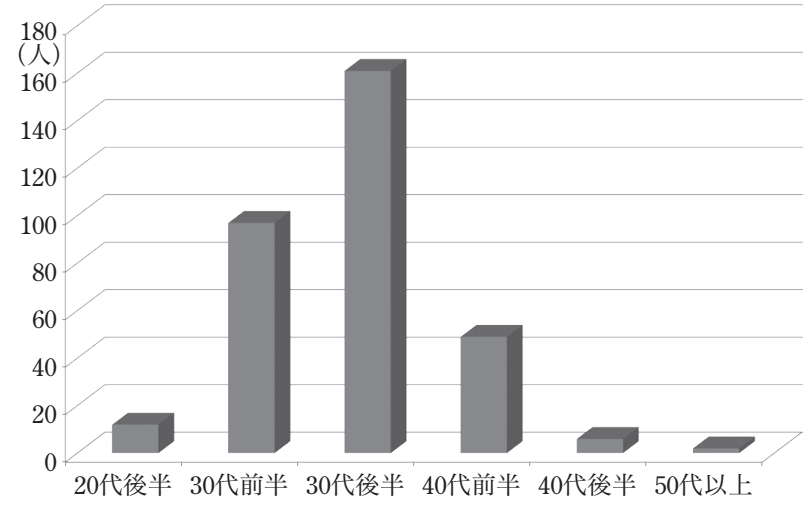

Fig. 4 Number of neurosurgeons by age at departure

Most neurosurgeons left in their late 30s.

とが大切である。ここでは，5項目について述べる。

\section{1. スーパーグローバル大学について}

全国で 37 大学がスーパーグローバル大学として指定 されている。これは 2014 年に指定されたもので, 大学の 国際競争力を向上させ，グローバルな舞台で活躍できる 人材の育成を目的としている。国立，私立，公立を問わ ず，トップ型指定校が 13 大学, グローバル化牽引型指定 校が 24 大学である。これらの大学では徹底した国際化 を進めて，世界レベルの教育研究を行うことと，多くの 講義を英語で行うことが求められている.

\section{2. 国際バカロレア入試について}

英語での教育が中心の国際バカロレア認定校の卒業者 にのみ国際バカロレア入試の受験資格がある。国際バカ 
ロレア認定校は全世界で 5,000 校，日本で 72 校 $(2020$ 年 10 月現在）であり, 卒業試験が世界共通であるのが特徴 である。 バカロレア入試は医学部でも導入が増えてお り, 現在, 国立 10 大学, 私立 2 大学が行っている。われ われの岡山大学医学部では 6 年前より国際バカロレア入 試をはじめており, 現在 1 学年で 5 名の定員となってい る。これらの認定校では, 英語での教育はもちろんだが, 加えてプレゼンテーションやコミュニケーションの教育 を受けていることが，通常の日本の高等学校との相違点 である。

\section{3. 医師国家試験への英語問題の出題}

医師国家試験は 2019 年までは 500 題の出題で，うち 2 題が英語の問題であったが, 2020 年には全体の問題数は 400 題に減ったにもかかわらず，4題が英語の問題にな り，グローバル時代を反映した状況となっている．実際 に外国人患者を診察する機会が以前に比べて増えている のは明らかなので，医師国家試験のレベルで，英語の重 要性を提示していることは適切な対応と考えられる。 ま た，2019年までの出題では, 問題や解答のすべてが英語 であったわけではなく, 英語と日本語が混じっていた が，2020 年の出題では, 問題文も解答文も完全に英語に
なっている (Fig. 7)。医師国家試験に英語の問題が多く 出題される状況となったので, 医学部での臨床実習でも 英語の重要性を学ばせる必要が増すと思われる。

\section{4. 国内学会の国際化}

多くの医学会で国際化が進んでいる. 学会の抄録を英

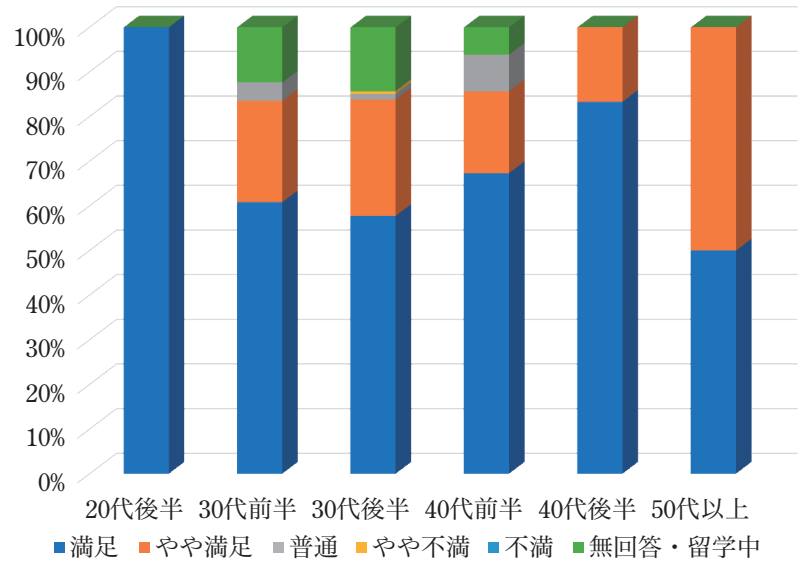

Fig. 5 Satisfaction by age

The majority of neurosurgeons who studied abroad at any age were satisfied or somewhat satisfied.

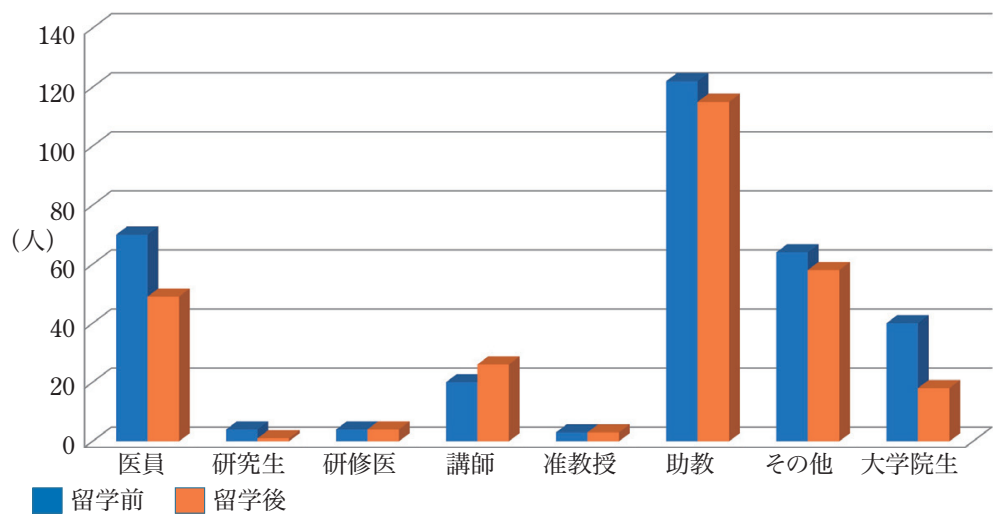

Fig. 6 Positions before and after study abroad In most cases, these physicians returned to the same position.

Table 1 Current status of neurosurgeons studying abroad

- The number of neurosurgeons studying abroad has been on a slight upward trend since 2010.

- The ratio of clinical study abroad is slightly increasing.

- The most common destination for study abroad is the United States, but the number of neurosurgeons studying in Germany and France is increasing.

- Most neurosurgeons study abroad in their late 30 s.

- Most of the respondents were satisfied with their study abroad experience in the post-study abroad interviews.

- The position before and after studying abroad is almost the same. 
語とする，あるいは発表スライドを英語とする学会はす でに多数ある。発表言語を英語だけ，としている学会は まだ多くはないが，英語でも日本語でも可とする学会は かなり多い。また，学会の機関誌もかなりの学会で英語 化が進んでいる。 日本脳神経外科学会ではすでに 30 年 以上前に機関誌である Neurologia medico-chirurgica の公 用語を英語としている.

これまでは国内学会への外国人の参加は, 特別講演な ぞでの招聘講演を別とすると，アジアの国からの参加が 大部分であったが, このたびの新型コロナ禍の影響で, いわゆるオンライン参加が一般的に広がることになっ た。そのため今後は時差の問題はあるものの, 欧米諸国 からの参加も比較的容易に行わ机ると予想され，国内学 会の国際化はさらに加速するのではないかと思われる。

\section{5. 日本脳神経外科学会およびコングレス総会での同 時通訳団の活動}

日本脳神経外科同時通訳団は 1987 年に創設された, 他の学会にはない，ユニークな組織である．基本的な活 動は，日本脳神経外科学会学術総会やコングレス総会で の外国人招待講演者や，日本国内の外国人留学生などを 対象に，日本人の講演を日 $\rightarrow$ 英に同時通訳をして，外国 人がスムースに討論に加われるようにすることである。 毎年夏期研修会を開催しており，トレーニングを行い， 若手メンバーをリクルートしている，詳しくは，私の論 文を参考にしていただきたい2．

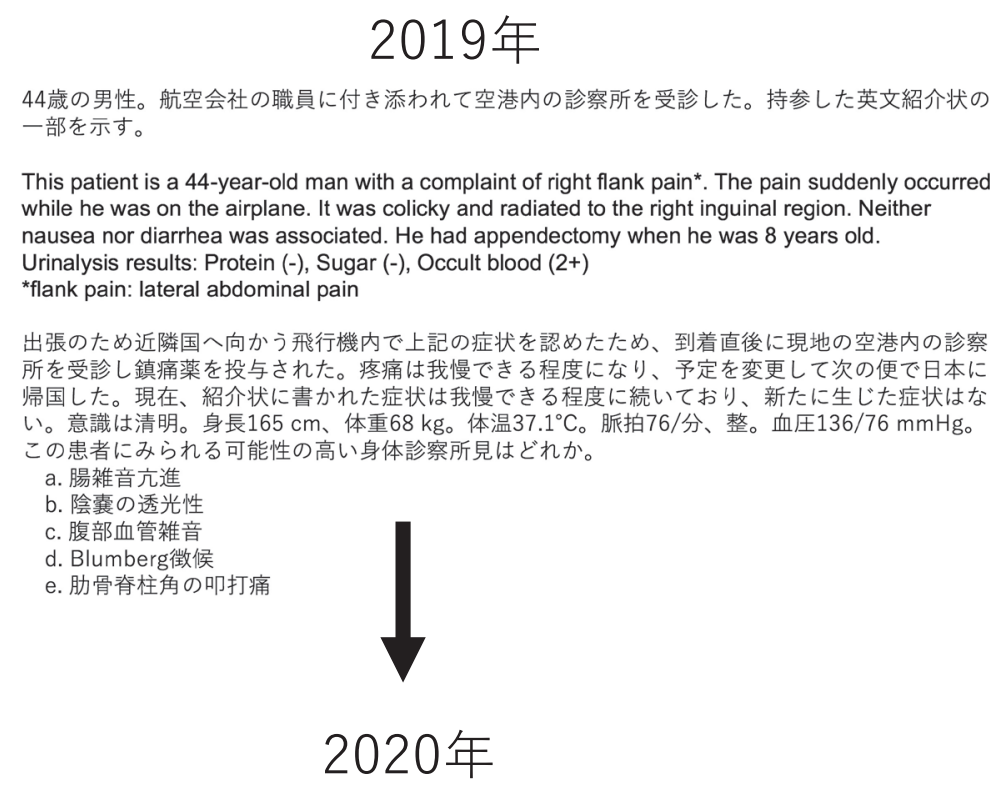

A 26-year-old woman presented to the emergency room with palpitations and shortness of breath that started suddenly while she was eating breakfast. Although the health-screening examination performed three weeks ago showed delta waves in her ECG, echocardiography taken at a nearby hospital showed no abnormal findings. At presentation, she was slightly hypotensive with a blood pressure of $96 / 68 \mathrm{mmHg}$. Her ECG on admission showed a narrow QRScomplex tachycardia at a rate of $180 / \mathrm{min}$. Neither ST elevation nor T wave abnormality was present.

What is the most probable diagnosis of the arrhythmia?

a. Sinus tachycardia

b. Sick sinus syndrome

c. Ventricular tachycardia

d. Supraventricular tachycardia

e. Complete atrioventricular block

Fig. 7 English questions for the national examination for medical practitioners

In 2020, all the questions and answers were written in English. 
内頝動脈海綿静脈洞部の巨大動脈瘤に

対しては,

以前から

IC ligation と

high flow bypass が

主として行なわれてきた。

最近になって,

血管内手術の発達により
Regarding IC cavernous giant aneurysms,

so far

IC ligation and

high flow bypass have been

mainly performed.

Recently,

due to development of

endovascular surgery,

Fig. 8 Examples of site translations

Showing translations from the beginning.

\section{Communication tool としての 英語の重要性}

脳神経外科医として活動していると，communication tool としての英語の重要性に否が応でも気づかされる. 最先端の論文を読んだり，書いたりはもちろん，自らの デー夕を国際学会で英語で発表し，討論することで世界 に認められる。若手脳神経外科医には, 専攻医時代も, 専門医になっても英語を学び続けていただきたい.デー 夕を得る $\rightarrow$ 国際学会で発表する $\rightarrow$ 英語論文化する $\rightarrow$ 外国 留学につなげる，この流机を普通の流机にすることが大 切である ${ }^{1)}$ 。 また, 日本に留学している外国人医師や研 究者との交流を大切にしてほしい. 日本脳神経外科学会 の関連学会である, 日本脳神経外科国際学会フォーラム （JNEF）は，国際学会での発表のトレーニングの場とし て有用である. 英語での発表の適当な機会であると同時 に抄録の書き方やスライドの作り方について，シニアメ ンバーから貴重な意見が聞ける。また，さらに英語力を 伸ばしたい人は，JNEF と同時に開催される同時通訳団 夏期研修会で同時通訳を学ぶのがよいだろう。同時通訳 のいろいろなコツを伝授してもらえるよい機会である. 自分の英語力を知るためには, 日本医学英語検定試験 (医英検) の受験を打勧めする.4 級（基礎級, 医学生レ ベル），3 級（応用級, 研修医レベル），2 級（プロフェッ ショナル級), 1 級 (エキスパート級) と難易度によって レベルが 4 つる。. 2 級は国際学会で自由に発表ができ るレベル， 1 級は 2 級レベルの人を指導できるレベル(国 際学会で座長を行えるレベル) である.

英語の練習は native とのやりとりが対面でできれば理 想であるが，そのような機会を得ることは困難なので, 一人で練習する方法を知っておくのも大切である。ここ では 3 つ紹介する.

\section{1. サイトトランスレーション（サイトラ）}

日本語の論文を読む際，ある一段落について英語訳を する練習をする，文章を型どおりに訳すのではなく，頭 から訳していくのである。これをフレーズトランスレー ションというが，同時通訳の練習としても有用である. 日本語を見てすぐ英語が浮かぶ習慣がつく。たとえば $\ulcorner$ 内頝動脈海綿静脈洞部の巨大動脈瘤に対しては, 以前 から IC ligtion と high flow bypass が主として行われてき た，最近になって，血管内手術の発達により…という 文章をサイトラするとどうなるかを Fig. 8 に記載した。

\section{2. シャドウイング}

Native speaker がプレゼンテーションしている英語の 動画を手に入れ，ヘッドセットでそれを聞きながら， 0.5 秒遅机くらいでそのまま発音してついていく，少しゆっ くり話している題材を用いるとやりやすい. 英語のリズ ムに慣れるのにいい方法である，また，英語の音声を自 分の口から発すること自体に意味がある。

\section{Talk to Siri}

iPhone やiPad など（他の機種でも）では，Siri という 音声認識アプリが付属している。それを英語用に設定 し，自分で論文などの英語を声に出して読んでいく. Siri は認識した英語をそのまま文字に変換してくれる。間 違った変換になる場合は，自分の発音が正確でないと判 断し，繰り返しその発音の練習をする。

\section{日本脳神経外科学会・日本脳神経外科 コングレスのグローバルな活動}

どちらの学会もグローバルな活動をしている. 日本脳 神経外科学会では，種々の 2 国間のカンファレンスをサ ポートしている。たとえば，日・印，日・独，日・中， 日・韓，日・露，などである。

WFNS（世界脳神経外科会議）に多くの役員を送って 


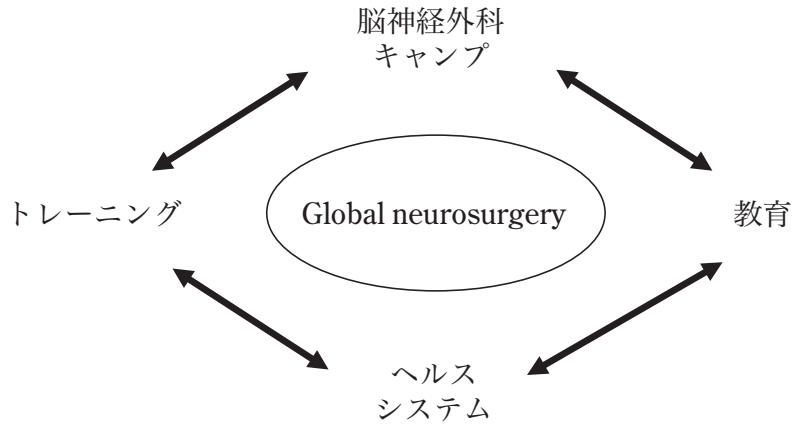

Fig. 9 Concept of global neurosurgery

いる. 現在, honorary president 4 名, secretary 1 名, audit committee 1 名, nominating committee 1 名, ad hoc committee として, education and training, mass casualties, neuro-oncology の委員長を 1 名ずつ担当している。 また WFNS では全世界で教育コースを運営しているが，これ らに日本脳神経外科学会から講師を派遣している。日本 脳神経外科コングレスでは, 毎年米国の会長が日本のコ ングレスで講演をし，日本の会長もしばしば米国のコン グレスから講演依頼を受けている。

\section{Global neurosurgery とは}

最近, global neurosurgery という用語がよく使われ， そのタイトルで論文も散見される ${ }^{3), 7)}$ 。これは概念とし ては世界レベルでの脳神経外科の発展を目指そうという もので, 特に発展途上国の脳神経外科の進歩を援助する 仕組みを考えよう，というものである。日本はどのよう に見られているかといえば，脳神経外科医が多く存在す る国であり, global neurosurgery に貢献できるパワーを もった国として認識されている. Fig.9にあるように global neurosurgery では次のようなステップを踏んでい くことが望まれる。まず最初のステップは, 脳神経外科 キャンプである。これは，専門医が発展途上国に出向い て手術を行うステップである。次に，発展途上国の脳神
経外科医に日本に留学してもらって教育とトレーニング を行うステップがある。そして最後は，留学から帰国し た医師がその国のヘルスシステムや医療施設の充実に貢 献するステップとなる（Fig. 9).

\section{おわりに}

2020 年 10 月現在，新型コロナウイルスはまだ世界に 感染が拡大しており，外国との間を自由に行き来できな い. グローバル時代に戻るのにはもう少し時間がかかり そうである。コロナ禍の中にあって，オンラインでの会 議や学会開催が一般的となり，インターネットを通じて のグローバル時代は再びやってきているといえる。すで に示したように外国に留学する日本の脳神経外科医は増 加傾向にあり，再び日本の若手脳神経外科医が世界で活 躍できる日々が早く戻ることを祈りたい.

COI 著者全員は日本脳神経外科学会への COI 自己申告の登 録を完了しており，筆頭著者が過去 3 年 1～12 月において本 論文に関して開示すべき COI は下記のとおりです。

桃太郎源株式会社より年間合計 200 万円以上

\section{文 献}

1）伊達 熏：脳神経外科医教育における基礎研究の意義. 脳外誌 $20 ： 115-122,2011$.

2）伊達 勲: 日本脳神経外科同時通訳団の活動。脳外速報 22:224-227, 2012.

3) Haglund MM, Fuller AT : Global neurosurgery : innovators, strategies, and the way forward. J Neurosurg 131:993999, 2019.

4）文部科学省：トビタテ！留学 JAPAN とは。 https://tobitate.mext.go.jp/about/(閲覧：2020 年 10 月)

5）文部科学省：報道発表「外国人留学生在籍状況調査」及 び「日本人の海外留学者数」等について. 2020 . https://www.mext.go.jp/content/20200421-mxt_ gakushi02-100001342_1.pdf（閲覧：2020 年 10 月）

6）野崎和彦：海外留学の実態調査および海外での基礎研究 の意義。脳外誌 21：452-457, 2012.

7) Servadei F, Rossini Z, Nicolosi F, Morselli C, Park KB : The role of neurosurgery in countries with limited facilities: facts and challenges. World Neurosurg 112:315-321, 2018 . 
旨

グローバル時代の脳神経外科

一若手へのメッセージー

伊達 勲 村井 智

予想もしなかったコロナ禍のために日本へのインバウンド, 日本からのアウトバウンドとも停止し た状態になっているが，これはやがて解決し，再びグローバル時代が到来すると期待している. 脳神 経外科医の外国への留学数は一時に比べれば増加傾向にある. 本稿では, 脳神経外科医の留学に関す るアンケート調査結果を示し, 留学の利点·課題, アカデミアがグローバル時代に向かう方向, communication tool としての英語の重要性, 日本脳神経外科学会ならびに日本脳神経外科コングレスのグ ローバルな活動, を解説し, 最後に global neurosurgery とはどういう概念かについて紹介した. 若手 脳神経外科医のグローバルな活躍を引き続き期待する. 